Edu Consilium: Jurnal BK Pendidikan Islam

Vol. 3, No. 1, 2022, hlm. 14-24

DOI: $10.19105 /$ ec.v1i1.1808

ISSN 2503-3417 (online)

ISSN 2548-4311 (cetak)

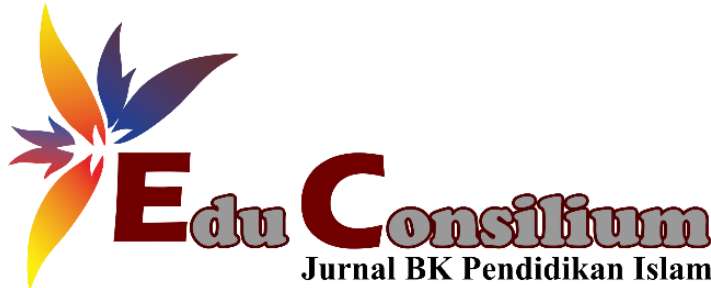

\title{
EFEKTIVITAS MINDFULNESS THERAPY DALAM MENINGKATKAN SELF ACCEPTANCE REMAJA BROKEN HOME: LITERATURE REVIEW
}

\author{
${ }^{1}$ Amida Cindy Septiana, ${ }^{2}$ Abdul Muhid \\ ${ }^{1,2}$ Program Studi Psikologi, Universitas Islam Negeri Sunan Ampel Surabaya, Indonesia \\ *amidacindy18@gmail.com
}

\begin{abstract}
Keywords:
Mindfulness

Therapy,

Self

Acceptance,

Broken

Home

Adolescents

Abstract

Divorce in parents will have an impact on the psychosocial condition of adolescents. The existence of parental divorce makes teenagers more vulnerable to having problems in the aspect of self-acceptance. Broken home teenagers often do some deviant behavior, such as skipping school, using illegal drugs, and so on. This is done by teenagers as an illustration that they have not been able to accept the conditions of the divorce. Thus, it is necessary to have psychological empowerment carried out for broken home teenagers to increase their self-acceptance. Purpose: The purpose of this literature review is to determine the effectiveness of mindfulness therapy in increasing self-acceptance of broken home adolescents. Method: The literature review method is used by collecting data about the phenomenon raised through various sources, both journals, books, and other references that are relevant to the issues and topics raised. Conclusion: mindfulness therapy is considered effective in increasing self-acceptance of broken home adolescents.
\end{abstract}

\begin{tabular}{ll}
\hline & Abstrak \\
\hline Kata Kunci: & Perceraian pada orang tua akan berdampak pada kondisi psikososial remaja. Adanya \\
Terapi Mindfulness, & perceraian orang tua membuat remaja lebih rentan memiliki masalah pada aspek \\
Penerimaan Diri, & penerimaaan diri. Remaja broken home seringkali melakukan beberapa perilaku \\
Remaja Broken & menyimpang, seperti membolos sekolah, memakai obat-obatan terlarang, dan sebagainya. \\
Home. & Hal tersebut dilakukan remaja sebagai gambaran bahwa mereka belum bisa menerima \\
& kondisi perceraian tersebut. Sehingga, perlu adanya pemberdayaan psikologis yang \\
& dilakukan kepada remaja broken home untuk meningkatkan self acceptance mereka. \\
& Tujuan : tujuan dilakukannya Literature review ini adalah untuk mengetahui efektivitas \\
& terapi mindfulness dalam meningkatkan penerimaan diri remaja broken home. Metode : \\
& Metode literature review digunakan dengan cara mengumpulkan data mengenai fenomena \\
& yang diangkat melalui berbagai sumber, baik jurnal, buku, maupun referensi lainnya yang \\
& relevan dengan masalah dan topik. Kesimpulan : terapi mindfulness dinilai efektif dalam \\
& meningkatkan self acceptance remaja broken home.
\end{tabular}




\section{PENDAHULUAN}

Masa remaja merupakan masa peralihan dari masa anak-anak menuju masa dewasa. Masa remaja dimulai pada usia 10-12 tahun dan berakhir pada usia 18-22 tahun (Santrock, 2018). Masa remaja dianggap sebagai masa yang penuh dengan storm dan stress (Fatchurrahmi \& Sholichah, 2021). Pada masa ini, banyak sekali terjadi konflik dan perubahan suasana hati pada diri remaja (Fatchurrahmi \& Sholichah, 2021). Selain itu, pada masa ini juga individu mulai mengalami beberapa perubahan, meliputi perubahan fisik, mental, sosial, dan emosionalnya. Menurut Nender et al. (2017), masa remaja adalah suatu masa dimana remaja berusaha untuk mencapai kematanagan perkembangan kepribadiannya yang dilakukan dengan cara mengenali, menyesuaikan, menerima, dan menilai diri sendiri secara positif. Dalam prosesnya, keluarga menjadi faktor yang paling penting untuk mendukung remaja menghadapi masa peralihan ini.

Keluarga adalah sekumpulan dari beberapa individu yang tinggal dan hidup bersama dalam hubungan darah atau ikatan pernikahan (Wulandri \& Fauziah, 2019). Undang-undang no. 52 tahun 2009 mendefinsikan keluarga sebagai suatu bagian atau kelompok terkecil dari masyarkat yang terdiri dari pasangan suami dan istri, ibu dengan anak, ayah dengan anak, atau suami, istri, dan anak (Wulandri \& Fauziah, 2019). Dalam masa remaja, keluarga mempunyai peran yang penting. Pertumbuhan dan perkembangan remaja sangat bergantung pada bagaimana peran keluarga terutama orang tua dalam memberikan contoh, memberikan pemahaman mengenai perubahan yang terjadi, serta memberikan dukungan untuk melewati masa transisi tersebut (Mamesah \& Kusumawardhani, 2020). Remaja yang berada dalam kondisi keluarga harmonis akan mendapatkan pengaruh yang baik bagi perkembangannya, sedangkan remaja yang berada dalam kondisi keluarga tidak harmonis, tidak rukun, sering cekcok, atau dapat dikatakan sebagai keluarga broken home akan mendapatkan pengaruh yang tidak baik bagi perkembangannya (Fauzia \& Listiyandini, 2018).

Pada kehidupan keluarga banyak terjadi konflik atau perselisihan antar anggota keluarga. Konflik yang terjadi mulai dari perbedaan pendapat, masalah anak yang tidak nurut, hingga perkelahian antara suami istri yang berujung pada perceraian (Mamesah \& Kusumawardhani, 2020). Selain itu, perceraian juga dikenal dengan istilah broken home. Willis (2015) menjelaskan bahwa broken home merupakan kondisi hilangnya rasa perhatian sesama anggota keluarga maupun minimnya rasa kasih sayang dari orang tua, dimana hal ini disebabkan oleh beberapa hal, salah satunya perceraian (Wulandri \& Fauziah, 2019). 
Data nasional mengenai jumlah perceraian yang tercatat pada Badan Pusat Statistik menunjukkan adanya peningkatan kasus rata-rata 9\% setiap tahunnya, mulai dari tahun 20012016 (182). Di masa pandemi ini, kasus perceraian juga menunjukkan adanya peningkatan. Pada bulan april-mei 2020 jumlah kasus perceraian yang berada dibawah 20.000 kasus meningkat menjadi 57.00 kasus pada bulan juni-juli. Selain itu, peningkatan angka perceraian juga dapat dilihat di beberapa wilayah di Indonesia, seperti di Ponorogo mencapai 2000 kasus per tahun (Berita soloraya, 2021), di Bandung Barat kasus perceraian mencapai 2.115 kasus (Detiknews, 2021), serta di Lamongan mencapai 200 kasus per bulan (Kompas, 2021).

Perceraian yang terjadi antara suami dan istri sangat memberikan dampak dan pengaruh bagi anak, terutama pada proses perkembangannya. Dalam kondisi keluarga yang bercerai atau broken home, hak anak untuk mendapatkan lingkungan keluarga yang nyaman dan harmonis tidak terpenuhi. Hal tersebut dikarenakan orang tua seringkali melibatkan anak dalam konflik yang terjadi. Remaja broken home lebih banyak mengalami masalah dibandingkan dengan remaja dengan keluarga yang harmonis (Fahrurrazi \& Casmini, 2020). Lestari mengemukakan bahwa perceraian yang tejadi berdampak pada perkembangan psikososial remaja. Remaja akan merasa tidak aman, stres, depresi, tidak mau berinteraksi dengan orang lain, merasa tidak lagi dicintai dan disayangi oleh kedua orang tuanya, merasa bersalah, hingga memiliki keinginan untuk bunuh diri (Fahrurrazi \& Casmini, 2020).

Aziz (2015) menemukan bahwa terdapat beberapa perilaku menyimpang yang dilakukan oleh remaja broken home. Perilaku-perilaku menyimpang tersebut, yaitu memiliki sikap tidak sopan terhadap orang lain, menurunnya motivasi untuk belajar, dan cenderung suka mencari perhatian. Sikap dan perilaku negatif yang ditunjukkan remaja tersebut merupakan suatu gambaran bahwa mereka belum bisa menerima kondisi yang terjadi dalam keluarga mereka (perceraian) (Fahrurrazi \& Casmini, 2020). Oleh karena itu, dapat dikatakan bahwa kondisi perceraian orang tua dapat menimbulkan dampak bagi self acceptance remaja (Fauzia \& Listiyandini, 2018).

Setiap perceraian yang terjadi tidak selalu berdampak negatif bagi remaja. Ada beberapa penelitian yang menemukan bahwa remaja yang mengalami perceraian orang tua mampu menyesuaikan diri terhadap kondisi tersebut. Hasil penelitian Amadea (dalam Fauzia \& Listiyandini, 2018) menunjukkan bahwa remaja dengan situasi perceraian orang tua mampu menerima diri, menerima keadaan, serta melihat perceraian sebagai suatu pembelajaran untuk masa depan. Berdasarkan penelitian yang dilakukan, Nender et al. (2017) juga menemukan hasil remaja broken home dapat secara positif menerima diri mereka. 
Penelitian-penelitian tersebut menunjukkan bahwa terdapat kesempatan bagi remaja broken home untuk memiliki aspek self acceptance yang baik dalam diri mereka. Self acceptance adalah sikap menerima diri secara positif, baik itu kelebihan maupun kekurangan yang dimiliki (Nender et al., 2017). Oleh karena itu, perlu adanya pemberdayaan yang dilakukan dalam meningkatkan self acceptance remaja broken home.

Self acceptance remaja broken home dapat diberdayakan dengan berbagai cara, salah satunya dengan mindfulness therapy. Menurut Savitri \& Listiyandini (2017), mindfulness memiliki peran yang signifikan dalam meningkatkan self acceptance remaja. Mindfulness adalah suatu perhatian individu atas pengalaman atau kondisi yang terjadi serta adanya keterbukaan dan penerimaan akan pengalaman atau kondisi tersebut. (Brown \& Ryan, 2003; Fauzia \& Listiyandini, 2018). Mindfulness therapy memiliki beberapa manfaat, meliputi membantu remaja sadar akan dirinya, mampu hidup dengan menerima segala sesuatu yang dimiliki, baik itu karakter, kekurangan maupun kelebihan, serta menerima berbagai pengalaman masa lalunya (Jannah, 2019).

Penelitian mengenai mindfulness therapy dan self acceptance masih kurang dan perlu untuk diteliti lebih lanjut. Penelitian mengenai self acceptance remaja broken home hanya berrfokus pada gambaran penerimaan diri remaja (Fahrurrazi \& Casmini, 2020, Mamesah \& Kusumawardhani, 2020, Nender et al., 2017). Penelitian-penelitian tersebut kurang menjelaskan bagaimana atau strategi apa yang perlu dilakukan untuk meningkatkan self acceptance remaja broken home. Hal tersebut merupakan alasan perlunya penelitian ini untuk dilakukan. Hasil dari penelitian ini diharapkan dapat berkontribusi dan memberikan informasi mengenai strategi pemberdayaan yang dapat dilakukan untuk meningkatkan penerimaan diri remaja broken home.

\section{METODE}

Studi ini dilakukan dengan menggunakan metode literature review. Tujuan studi ini dilakukan adalah melihat efektivitas mindfulness therapy dalam meningkatkan self acceptance remaja broken home. Metode ini dilakukan dengan cara melakukan pencarian artikel yang sudah terpublikasi dan relevan dengan topik yang dibahas, yaitu mengenai efektivitas mindfulness therapy dalam meningkatkan self acceptance remaja broken home. Artikel dikumpulkan melalui beberapa database, yaitu Google Sholar, Garuda, dan Science Direct. Pencarian artikel dalam beberapa database tersebut dilakukan dengan cara memasukkan beberapa kata kunci, seperti "penerimaan diri pada remaja broken home", "self 
acceptance", "mindfulness", "mindfulness dan penerimaan diri". Artikel yang digunakan adalah artikel dengan publikasi tahun 2015 sampai 2021.

\section{HASIL}

\section{Penerimaan Diri}

Penerimaan diri merupakan kemampuan individu untuk berhubungan secara positif dengan dirinya dan pengalamannya (Fauzia \& Listiyandini, 2018). Hurlock (2006) menyatakan bahwa self acceptance merupakan kemampuan dan keinginan individu untuk hidup dengan semua karakter atau keunikan yang dimilikinya (Hurlock, 2006; Mamesah \& Kusumawardhani, 2020). Xu et al. (2017) mendefinisikan penerimaan diri sebagai sikap positif individu terhadap segala aspek di masa lalu, masa kini, dan masa depan. Dari beberapa definisi tersebut dapat disimpulkan bahwa penerimaan diri merupakan kemampuan individu untuk mempersepsikan atau menilai dirinya secara positif serta mampu untuk menerima segala hal yang dimiliki, baik itu kelebihan maupun kekurangan.

Penerimaan diri dianggap sebagai faktor kepribadian yang sangat penting bagi kesehatan mental seseorang, dimana dengan adanya penerimaan diri individu dapat terhindar dari stress, depresi, kecemasan, serta gangguan mental lainnya (Nender et al., 2017). Chen et al. (2017) juga menyatakan bahwa penerimaan diri berperan penting bagi kesehatan mental individu, dimana semakin tinggi tingkat self acceptance seseorang maka semakin rendah tingkat depresi yang dimiliki. Adapun, Carson dan Langer (2006) menyatakan bahwa individu dengan tingkat self acceptance yang tinggi akan mampu mengatasi segala kesulitan emosional yang dialami, seperti kemarahan yang tidak terkendali dan depresi (Carson \& Langer, 2006; Lena et al., 2021).

Rahayu \& Fatimah (2018) menyatakan bahwa penerimaan diri adalah sebuah langkah awal seseorang dalam membentuk kepribadian diri yang positif. Individu yang memilki self acceptance cenderung lebih rasional atau objektif dalam menilai dirinya, mampu menerima apa yang dimiliki, dan tidak menghakimi serta memandang negatif kekurangan yang dimiliki (Fauzia \& Listiyandini, 2018). Individu yang memiliki penerimaan diri mampu mengembangkan serta mengelola berbagai potensi yang dimiliki (Nender et al., 2017). Penerimaan diri dibagi menjadi 2 aspek. Menurut Bernard, 2 aspek yang ada dalam

penerimaan diri adalah (1) kesadaran diri, penghargaan akan karakteristik positif dan pengembangan potensi dan (2) rasa bangga, menerima tanpa syarat atas peristiwa negatif 
yang terjadi, serta menilai diri sendiri secara positif tidak (Bernard, 2013; Waney et al., 2020).

Penerimaan diri dibentuk oleh beberapa faktor. Menurut Hurlock (2006), faktor-faktor yang membentuk penerimaan diri adalah pemahaman diri (self understanding), harapan yang realistis (realistic aspiration), tidak adanya hambatan lingkungan (absence of environment obstacles), sikap sosial yang positif (social insight), pola asuh yang baik, dan konsep diri yang stabil (stable self concept) (Hurlock, 2006; Mamesah \& Kusumawardhani, 2020). Berger (1952) mengemukakan terdapat beberapa karakteristik yang dimiliki individu dengan penerimaan diri. Karakteristik tersebut, meliputi mengandalkan standard diri sendiri sebagai lawan dari tekanan eksternal, memiliki keyakinan akan kemampuannya dalam mengatasi berbagai masalah, memiliki rasa tanggung jawab, mampu merima segala akibat dari tindakan yang dilakukan atau perilakunya, mampu menilai secara rasional segala kritik atau pujian yang diterima, melihat diri sendiri sebagai orang yang berharga dan setara dengan orang lain, tidak merasa insecure, melakukan segala upaya untuk mempertahankan sikap positif terhadap dirinya, serta menerima kekurangan dan keterbatasan yang dimiliki (Berger, 1952; Plexico et al., 2019).

\section{Terapi Mindfulness}

Mindfulness (rasa kesadaran) adalah perhatian terhadap pengalaman yang dengan ditandai adanya penerimaan dan keterbukaan terhadap pengalaman tersebut (Brown \& Ryan, 2003; Fauzia \& Listiyandini, 2018). Baer et al. (2006) mendefinisikan mindfulness sebagai keadaan sadar dan perhatian seseorang yang dilakukan dengan cara fokus akan pengalaman atau kondisi saat ini dan mampu menerima tanpa menilai pengalaman tersebut. (Baer et al., 2006; Savitri \& Listiyandini, 2017). Mindfulness adalah perhatian individu atas pengalaman atau kondisi yang terjadi serta adanya penerimaan (acceptance) akan pengalaman atau kondisi tersebut (Hayes et al., 2004; Yusainy et al., 2018). Mindfulness dipengaruhi oleh beberapa faktor. Kecerdasan emosi, kesejahteraan psikologis, dan regulasi diri menjadi faktor yang mempengaruhi mindfulness (Fauzia \& Listiyandini, 2018).

Mindfulness memiliki beberapa aspek di dalamnya. Lange berpendapat bahwa mindfulness memiliki empat aspek, yaitu memandang suatu peristiwa, kondisi, atau situasi tidak hanaya dari sati persooektif melainkan dari berbagai perspektif, melihat informasi yang sebagai suatu hal baru, memperhatikan di mana seseorang menerima informasi tersebut, dan membuat kategori baru dimana informasi tersebut dapat dipahami (Waney et al., 2020). 
Mindfulness memiliki tiga dimensi menurut Baer et al. (2006), dimana tiga dimensi tersebut, yaitu acting with awareness, observing, dan accepting without judgment. Acting with awareness yaitu menyadari atau memperhatikan tindakan yang dilakukan dengan cara menciptakan kesadaran saat ini. Dimensi selanjutnya observing, yaitu kemampuan untuk memahami rangsangan internal seperti, pemikiran, perasaan dan sensasi tubuh. Adapun, accepting without judgment, yaitu memperhatikan dan menerima suatu kondisi atau pengalaman tanpa menilainya.

Mindfulness individu satu dengan yang lain tidak sama tetapi dapat dikembangkan melalui pelatihan mindfulness (Brown et al., 2007; Erpiana \& Fourianalistyawati, 2018). Praktik mindfulness therapy dibedakan menjadi 2 jenis, yaitu praktik secara formal dan informal (Waney et al., 2020). Praktik terapi mindfulness kategori formal dilakukan dengan cara yang sama dengan meditasi, dimana terdapat beberapa metode yang dapat digunakan, yaitu kesadaran terhadap pernapasan yang dimiliki (mindfulness of breathing), kesadaran akan sensasi fisik (mindfulness of sensation), kesadaran terhadap suara yang didengar (mindfulness of hearing), kesadaran akan pikiran dan emosi (mindfulness of thoughts and emotions), serta Choiceless awareness. Adapun, cara atau metode yang dilakukan dalam praktik mindfulness therapy secara informal, yaitu sadar akan aktivitas, kebiasaan, atau perilaku sehari-hari, seperti merasakan sensasi saat minum kopi, jalan dengan perhatian penuh, dan sebagainya (Waney et al., 2020). Terapi mindfulness dapat dilakukan atau diberikan secara individual maupun kelompok yang memiliki permasalahan fisik dan psikologis, termasuk remaja broken home (Wuryansari \& Subandi, 2019).

\section{Efektivitas Mindfulness Therapy dalam Meningkatkan Sefl Acceptance Remaja Broken}

\section{Home}

Berdasarkan pencarian dari beberapa penelitian sebelumnya yang menggunakan mindfulness, menunjukkan hasil bahwa mindfulness therapy mempunyai beberapa manfaat, terutama dalam meningkatkan psychological weel being individu. Hal tersebut dapat dibuktikan dengan beberapa hasil penelitian sebelumnya. Baer et al. (2006) menyatakan bahwa mindfulness therapy memiliki pengaruh dan hubungan yang positif dengan kesejahteraan psikologis individu (Baer et al., 2006; Savitri \& Listiyandini, 2017). Kesejahteraan psikologis memiliki beberapa dimensi, dimana salah satunya adalah self 
acceptance. Oleh karena itu, dapat dikatakan bahwa secara tidak langsung mindfulness therapy berpengaruh terhadap meningkatnya self acceptance individu.

Self acceptance adalah salah satu aspek psikologis yang sangat penting bagi kesehatan mental atau jiwa seseorang, dimana peryataan ini sejalan dengan pendapat Nender et al. (2017) bahwa dengan adanya self acceptance individu dapat terhindar dari berbagai masalah psikologis, seperti depresi, kecemasan, stres, serta gangguan mental lainnya. Institute Meditation and Psychotherapy mengemukakan bahwa dengan dilakukannya terapi mindfulness berpengaruh terhadap meningkatnya kesadaran individu terhadap pengalaman atau kondisi yang terjadi serta sikap menerima pengalaman atau kondisi tersebut (Erpiana \& Fourianalistyawati, 2018). Selain itu, Rodriguez et al. (2015) mengemukakan bahwa dimensi non-reactivity yang ada didalam mindfulness therapy juga berpengaruh terhadap selfacceptance, dimana dimensi ini membuat individu berusaha untuk menerima dirinya serta tidak bereaksi atau menilai secara langsung kondisi yang terjadi.

Mindfulness therapy membantu individu menerima dirinya secara positif, meningkatkan kemampuan dalam membangun hubungan yang baik dengan orang lain, meningkatkan rasa kemandirian, mengendalikan lingkungan, memiliki tujuan hidup, dan mampu mengembangkan segala potensi yang dimiliki (Fatchurrahmi \& Sholichah, 2021). Menurut Marotta (2013), penerimaan diri dapat dicapai individu dengan cara memperkuat kesadaran atau keadaan mindful. Marotta (2013) menyatakan bahwa mindfulness membuat individu mampu menerima dirinya dan tidak lagi memiliki keinginan untuk menjadi yang sebaliknya atau bertentangan dengan apa yang dimiliki. (Marotta, 2013; Waney et al., 2020). Sejalan dengan pendapat Marotta, Xiao et al. (2017) menyatakan bahwa mindfulness therapy dapat membuat perubahan positif pada self acceptance remaja. Waney et al. (2020) dalam penelitiannya menemukan hasil bahwa mindfulness therapy dapat dijadikan sebagai suatu strategi yang dilakukan untuk meningkatkan self acceptance pada remaja.

Penerimaan diri sangat penting dimiliki oleh remaja broken home. Remaja broken home dengan self acceptance yang baik akan mampu membuat dirinya menerima segala kondisi yang terjadi (kondisi keluarga yang tidak lagi utuh), serta semua kekurangan yang dimiliki (Nender et al., 2017). Sebaliknya, jika remaja broken home memiliki self acceptance yang buruk maka akan membuat mereka merasa bersalah, merasa ditolak, tidak dicintai oleh orang tuanya, memandingkan kekurangan yang dimiliki dengan kelebihan orang lain, serta hanya akan selalu melihat kekurangan yang dimiliki (Nender et al., 2017). Mindfulness therapy mampu meningkatkan self acceptance remaja broken home. Pernyataan tersebut 
didukung oleh pendapat Carson \& Langer (2006) bahwa self acceptance yang positif dapat dimiliki seseorang dengan cara mereka harus mampu secara sadar merasakan setiap hal atau aktivitas yang dilakukan. Contohnya ketika remaja dihadapkan pada kondisi perceraian orang tua, remaja secara sadar merasakan kondisi tersebut, melihat kondisi dari berbagai sisi dan tidak langsung menghakimi diri (seperti saya yang salah, saya pantas menerima ini, dan sebagainya).

Efektivitas penerapan mindfulness therapy dalam meningkatkan penerimaan diri remaja broken home dapat dibuktikan dengan beberapa hasil penelitian sebelumnya mengenai pengaruh mindfulness therapy terhadap self acceptance remaja broken home. Beberapa hasil penelitian sebelumnya menunjukkan adanya perubahan tingkat self acceptance remaja broken home secara signifikan seletah diberikan terapi mindfulness. Penelitian yang dilakukan oleh Fauzia \& Listiyandini (2018) mengenai peran mindfulness dalam meningkatkan self acceptance remaja broken home menunjukkan hasil bahwa terapi mindfulness berperan secara positif dalam meningkatkan self acceptance remaja broken home. Terapi mindfulness memiliki peran yang positif terhadap penerimaan diri.

Selain dari hasil penelitian yang dilakukan Fauzia \& Listiyandini (2018), hasil yang signifikan juga dijelaskan oleh Jannah (2019) bahwa terapi mindfulness memiliki berperan positif dan signifikan dalam meningkatkan self acceptance remaja broken home. Setelah diberikan terapi ini, responden menunjukkan perubahan tingkat penerimaan diri. Tingkat penerimaan diri yang dimiliki semakin meningkat setelah terapi mindfulness dilakukan. Mindfulness ini diharapkan dapat meningkatkan psychological well being individu, terutama pada aspek self acceptance. Adanya self acceptance yang tinggi, membuat remaja broken home mampu menerima segala kondisi yang dihadapi.

\section{SIMPULAN}

Berdasarkan pembahasan di atas dengan judul efektivitas mindfulness therapy dalam meningkatkan self acceptance remaja broken home, dapat ditarik kesimpulan bahwa mindfulness therapy dinilai efektif dalam meningkatkan self acceptance remaja broken home. Mindfulness therapy memberikan beberapa dampak positif dan efektif sebagai intervensi individual dengan kasus serupa. Intervensi ini dilakukan untuk membantu remaja menerima segala kondisi akibat perceraian orangtua. Dari beberapa penelitian menunjukkan adanya peningkatan self acceptance yang signifikan setelah mindfulness therapy dilakukan. Dalam 
praktiknya, mindfulness therapy dibedakan menjadi 2 jenis, yaitu praktik secara formal dan informal.

\section{DAFTAR PUSTAKA}

Aziz, M. (2015). Perilaku Sosial Anak Remaja Korban Broken Home dalam Berbagai Perspektif (Suatu Penelitian di SMPN 18 Kota Banda Aceh). Jurnal Al-Ijtimaiyyah, 1(1), 30-50. https://doi.org/10.22373/al-ijtimaiyyah.v1i1.252

Baer, R. A., Smith, G. T., Hopkins, J., Krietemeyer, J., \& Toney, L. (2006). Using SelfReport Assessment Methods to Explore Facets of Mindfulness. Assessment, 13(1), 27-45. https://doi.org/10.1177/1073191105283504

Berger, E. M. (1952). The Relation Between Expressed Acceptance of Self and Expressed Acceptance of Others. Journal of Abnormal and Social Psychology, 47(4), 778-782. https://doi.org/10.1037/h0061311

Bernard, M. E. (2013). The Strength of Self-Acceptance : Theory, Practice and Research (1st ed.). Springer. https://doi.org/10.1007/978-1- 4614-6806-6

Brown, K. W., \& Ryan, R. M. (2003). The Benefits of Being Present: Mindfulness and Its Role in Psychological Well-Being. Journal of Personality and Social Psychology, 84(4), 822-848. https://doi.org/10.1037/0022-3514.84.4.822

Brown, K. W., Ryan, R. M., \& Creswell, J. D. (2007). Mindfulness: Theoretical Foundations and Evidence for its Salutary Effects. Psychological Inquiry, 18(4), 211-237. https://doi.org/10.1080/00952990.2016.1188935

Carson, S. H., \& Langer, E. J. (2006). Mindfulness and Self-Acceptance. Journal of Rational - Emotive and Cognitive - Behavior Therapy, 24(1), 29-43. https://doi.org/10.1007/s10942-006-0022-5

Chen, S. Q., Liu, J. E., Zhang, Z. X., \& Li, Z. (2017). Self-Acceptance and Associated Factors Among Chinese Women With Breast Cancer. Journal of Clinical Nursing, 26(11-12), 1516-1523. https://doi.org/10.1111/jocn.13437

Erpiana, A., \& Fourianalistyawati, E. (2018). Peran Trait Mindfulness terhadap Psychological Well-Being pada Dewasa Awal. Psympathic : Jurnal Ilmiah Psikologi, 5(1), 67-82. https://doi.org/10.15575/psy.v5i1.1774

Fahrurrazi, F., \& Casmini, C. (2020). Bimbingan Penerimaan Diri Remaja Broken Home. ENLIGHTEN (Jurnal Bimbingan Dan Konseling Islam), 3(2), 142-152. https://doi.org/10.32505/enlighten.v3i2.1674

Fatchurrahmi, R., \& Sholichah, M. (2021). Mindfulness for Adolescents from Broken Home Family. International Journal of Latest Research in Humanities and Social Science (IJLRHSS), 04(02), 60-65.

Fauzia, R., \& Listiyandini, R. A. (2018). Peran Trait Mindfulness (Rasa Kesadaran) Terhadap Penerimaan Diri pada Remaja Dengan Orangtua Bercerai. Seminar Nasional Dan Temu Ilmiah Positive Psikologi, 152-163.

Hayes, S. C., Follette, V. M., \& Linehan, M. M. (2004). Mindfulness and Acceptance: Expanding The Cognitive-Behavioral Tradition. Guilford Press.

Hurlock, E. B. (2006). Psikologi Perkembangan: Suatu Pendekatan Sepanjang Rentang Kehidupan. Erlangga.

Jannah, A. M. (2019). Hubungan Mindfulness dan Penrimaan Diri pada Remaja dengan Orang Tua Tunggal. Universitas Muhammadiyah Malang.

Lena, A. T., Damayanti, Y., \& Benu, J. M. Y. (2021). Our Stories: A Woman, A Teenager, A Single Mother: Psychological Well-being of a Single Mother Adolescents. Journal of 
Health and Behavioral Science, 3(3), 360-380.

Mamesah, M., \& Kusumawardhani, D. D. (2020). Gambaran Penerimaan Diri Siswa yang Mengalami Perceraian Orangtua. INSIGHT: Jurnal Bimbingan Konseling, 9(2), 138149. https://doi.org/10.21009/insight.092.04

Marotta, J. (2013). 50 Mindful Steps to Self-Esteem : Everyday Practices for Cultivating SelfAcceptance and Self-Compassion. New Harbinger Publications.

Nender, E. W. A., Widyawati, S., \& Savitri, A. D. (2017). Penerimaan Diri pada Remaja Yang Orangtuanya Bercerai. Jurnal Psikologi Universitas Semarang, 10-18.

Plexico, L. W., Erath, S., Shores, H., \& Burrus, E. (2019). Self-Acceptance, Resilience, Coping and Satisfaction of Life in People Who Stutter. Journal of Fluency Disorders, 59(October), 52-63. https://doi.org/10.1016/j.jfludis.2018.10.004

Rahayu, W. D., \& Fatimah, M. (2018). Gambaran Konsep Diri Siswi yang Mengalami Broken Home (Studi Kasus pada 2 Siswi SMK Bunga Persada Cianjur yang Mengalami Broken Home). Fokus, 1(2), 52-57.

Rodriguez, M. A., Xu, W., \& Wang, X. (2015). Self-Acceptance Mediates the Relationship between Mindfulness and Perceived Stress. Psychol Rep, 116(2). https://doi.org/doi.org/10.2466\%2F07.PR0.116k19w4

Santrock, J. W. (2018). Life-Span Development: Perkembangan Masa Hidup (13th ed.). Erlangga.

Savitri, W. C., \& Listiyandini, R. A. (2017). Mindfulness dan Kesejahteraan Psikologis pada Remaja. Psikohumaniora: Jurnal Penelitian Psikologi, 2(1), 43-59. https://doi.org/10.21580/pjpp.v2i1.1323

Waney, N. C., Kristinawati, W., \& Setiawan, A. (2020). Mindfulness Dan Penerimaan Diri Pada Remaja Di Era Digital. Insight: Jurnal Ilmiah Psikologi, 22(2), 73. https://doi.org/10.26486/psikologi.v22i2.969

Willis, S. S. (2015). Konseling Keluarga (Family Counseling). Alfabet.

Wulandri, D., \& Fauziah, N. (2019). Pengalaman Remaja Korban Broken Home (Studi Kualitatif Fenomenologis). Empati, 8(1), 1-9.

Wuryansari, R., \& Subandi, S. (2019). Program Mindfulness for Prisoners (Mindfulners) untuk Menurunkan Depresi pada Narapidana. Gadjah Mada Journal of Professional Psychology (GamaJPP), 5(2), 196-212. https://doi.org/10.22146/gamajpp.50626

Xiao, Q., Yue, C., He, W., \& Yu, J. Y. (2017). The Mindful Self: A Mindfulness-Enlightened Self-View. Frontiers in Psychology, 8(1752), 1-10. https://doi.org/10.3389/fpsyg.2017.01752

Xu, W., Zhou, Y., Fu, Z., \& Rodriguez, M. (2017). Relationships Between Dispositional Mindfulness, Self-Acceptance, Perceived Stress, and Psychological Symptoms in Advanced Gastrointestinal Cancer Patients. Psycho-Oncology, 26(12), 2157-2161. https://doi.org/10.1002/pon.4437

Yusainy, C., Nurwanti, R., Dharmawan, I. R. J., Andari, R., Mahmudah, M. U., Tiyas, R. R., Husnaini, B. H. M., \& Anggono, C. O. (2018). Mindfulness Sebagai Strategi Reegulasi Emosi. Jurnal Psikologi, 17(2), 174-188. https://doi.org/10.14710/jp.17.2.174-188 